\title{
A Single Dose of LSD Does Not Alter Gene Expression of the Serotonin 2A Receptor Gene (HTR2A) or Early Growth Response Genes (EGR1-3) in Healthy Subjects
}

\author{
Patrick C. Dolder ${ }^{1}$, Edna Grünblattt,3,4, Felix Müller ${ }^{5}$, Stefan J. Borgwardt ${ }^{5}$ and \\ Matthias E. Liechti ${ }^{*}$
}

'Division of Clinical Pharmacology and Toxicology, Department of Biomedicine and Department of Clinical Research, University Hospital Basel and University of Basel, Basel, Switzerland, ${ }^{2}$ Department of Child and Adolescent Psychiatry and Psychotherapy, Psychiatric Hospital, University of Zurich, Zurich, Switzerland, ${ }^{3}$ Neuroscience Center Zurich, University of Zurich and ETH Zurich, Zurich, Switzerland, ${ }^{4}$ Zurich Center for Integrative Human Physiology, University of Zurich, Zurich, Switzerland, ${ }^{5}$ Department of Psychiatry (Universitäre Psychiatrische Kliniken Basel), University of Basel, Basel, Switzerland

\section{OPEN ACCESS}

Edited by:

Andrew Robert Gallimore, Okinawa Institute of Science and Technology, Japan

Reviewed by:

Attila Szabo,

University of Oslo, Norway Jean-Philippe Guilloux, Université Paris-Sud, France

*Correspondence:

Matthias E. Liechti matthias.liechti@usb.ch

Specialty section: This article was submitted to

Neuropharmacology,

a section of the journal Frontiers in Pharmacology

Received: 20 April 2017 Accepted: 14 June 2017 Published: 28 June 2017

Citation:

Dolder $P C$, Grünblatt E, Müller $F$, Borgwardt SJ and Liechti ME (2017) A Single Dose of LSD Does Not Alter Gene Expression of the Serotonin 2A Receptor Gene (HTR2A) or Early Growth Response Genes (EGR1-3) in Healthy Subjects.

Front. Pharmacol. 8:423. doi: 10.3389/fphar.2017.00423
Rationale: Renewed interest has been seen in the use of lysergic acid diethylamide (LSD) in psychiatric research and practice. The repeated use of LSD leads to tolerance that is believed to result from serotonin $(5-\mathrm{HT}) 5-\mathrm{HT}_{2 \mathrm{~A}}$ receptor downregulation. In rats, daily LSD administration for 4 days decreased frontal cortex $5-\mathrm{HT}_{2 \mathrm{~A}}$ receptor binding. Additionally, a single dose of LSD acutely increased expression of the early growth response genes EGR1 and EGR2 in rat and mouse brains through 5- $\mathrm{HT}_{2 \mathrm{~A}}$ receptor stimulation. No human data on the effects of LSD on gene expression has been reported. Therefore, we investigated the effects of single-dose LSD administration on the expression of the 5- $\mathrm{HT}_{2 \mathrm{~A}}$ receptor gene (HTR2A) and EGR1-3 genes.

Methods: mRNA expression levels were analyzed in whole blood as a peripheral biomarker in 15 healthy subjects before and 1.5 and $24 \mathrm{~h}$ after the administration of LSD $(100 \mu \mathrm{g})$ and placebo in a randomized, double-blind, placebo-controlled, crossover study.

Results: LSD did not alter the expression of the HTR2A or EGR1-3 genes 1.5 and $24 \mathrm{~h}$ after administration compared with placebo.

Conclusion: No changes were observed in the gene expression of LSD's primary target receptor gene or genes that are implicated in its downstream effects. Remaining unclear is whether chronic LSD administration alters gene expression in humans.

Keywords: LSD, serotonin receptor, gene expression, healthy subjects

\section{INTRODUCTION}

Lysergic acid diethylamide (LSD) is a well-known psychoactive substance that transiently alters mind and perception. During the last few years, renewed interest has been seen in the use of LSD in psychiatric research and practice (Liechti, 2017). Modern experimental studies in humans have reported LSD's subjective, autonomic, and endocrine effects (Schmid et al., 2015; Carhart-Harris et al., 2016a; Dolder et al., 2016; Strajhar et al., 2016; Liechti et al., 2017), 
functional brain activation patterns (Carhart-Harris et al., 2016b; Lebedev et al., 2016; Tagliazucchi et al., 2016; Preller et al., 2017), and pharmacokinetics (Dolder et al., 2015b, 2017). However, many aspects of LSD's pharmacological effects remain unclear, including the phenomenon of the rapid development of tolerance (i.e., tachyphylaxis) to its psychological and physiological effects with repeated administration (Passie et al., 2008). Early studies that employed repeated daily administration of $100 \mu \mathrm{g}$ LSD in humans described partial tolerance with the second dose and complete tolerance with the third and subsequent doses (Cholden et al., 1955; Abramson et al., 1956; Belleville et al., 1956). The effects of LSD reappeared only after a substance-free interval of 4 days. Tolerance to LSD is believed to result from serotonin $5-\mathrm{HT}_{2 \mathrm{~A}}$ receptor downregulation (Nichols, 2016). LSD potently binds to the $5-\mathrm{HT}_{2 \mathrm{~A}}$ receptor (Wacker et al., 2017) where it acts as a partial agonist (Rickli et al., 2016). Pretreatment with the $5-\mathrm{HT}_{2 \mathrm{~A}}$ receptor antagonist ketanserin completely prevented all perceptual and mind-altering effects of LSD in humans (Kraehenmann et al., 2017; Preller et al., 2017), indicating that the hallucinogenic effects of LSD are primarily mediated through 5$\mathrm{HT}_{2 \mathrm{~A}}$ receptors. Similar to humans, tolerance to the behavioral effects of LSD is also observed in rats (Buchborn et al., 2015). Consistent with a role for $5-\mathrm{HT}_{2 \mathrm{~A}}$ receptors in the development of tolerance, daily LSD administration for 3 days decreased 5$\mathrm{HT}_{2 \mathrm{~A}}$ receptor binding in the rat frontal cortex (Buckholtz et al., 1985, 1990; Gresch et al., 2005). However, another study reported only a non-significant trend toward a reduction of frontocortical $5-\mathrm{HT}_{2 \mathrm{~A}}$ receptor binding in rats during the development of tolerance to LSD (Buchborn et al., 2015). Additionally, no effects of acute LSD on $5-\mathrm{HT}_{2 \mathrm{~A}}$ receptor mRNA expression were found in the rat prefrontal cortex, hippocampus, or midbrain (Nichols and Sanders-Bush, 2002), although the effects of repeated LSD administration were not studied. Instead, adaptations in glutamate receptors were observed (Buchborn et al., 2015). Indeed, a key mechanism of action of LSD is the activation of frontal cortex glutamate transmission secondary to $5-\mathrm{HT}_{2 \mathrm{~A}}$ receptor stimulation (Gonzalez-Maeso et al., 2008; Moreno et al., 2011; Buchborn et al., 2015). Thus, adaptive changes that underlie tolerance to LSD may be reflected by alterations in the expression of genes that are involved in glutamatergic signaling or genes that regulate $5-\mathrm{HT}_{2 \mathrm{~A}}$ receptor function or its downstream signaling pathways. Acute LSD increased the expression of immediate early genes in the rat prefrontal cortex, including EGR2 (i.e., a gene that is involved in cognition and neural plasticity) and several others genes (Nichols and Sanders-Bush, 2002; Nichols et al., 2003; Nichols and Sanders-Bush, 2004). Further animal studies showed that LSD also increased the expression of EGR2 and EGR1 in the mouse cortex via $5-\mathrm{HT}_{2 \mathrm{~A}}$ receptor stimulation (GonzalezMaeso et al., 2003, 2007). Finally, LSD was shown to produce a characteristic transcriptome signaling pattern in normal but not HTR2A $A^{-/-}$mice (Gonzalez-Maeso et al., 2007).

Despite the renewed interest in the clinical use of LSD, no human studies on the effects of LSD on gene expression have been performed. Therefore, we investigated the effects of a single dose of LSD on the expression of the $5-\mathrm{HT}_{2 \mathrm{~A}}$ receptor gene (HTR2A) and EGR1-3 genes. The EGR1 and EGR2 genes were studied based on preclinical data (Gonzalez-Maeso et al., 2003, 2007), and the
EGR3 gene was studied because it has been shown to regulate HTR2A expression (Maple et al., 2015).

Acute changes in gene expression cannot be determined in heathy human brain tissue, as biopsy or postmortem tissue is not available. However, mRNA level changes in blood for candidate genes including EGR and HTR2A can cautiously be used as peripheral markers of transcription alterations in the CNS in response to interventions or to characterize patient groups (Sullivan et al., 2006; Mohr and Liew, 2007; Desjardins et al., 2008; Belzeaux et al., 2010; Rollins et al., 2010; Rivera-Baltanas et al., 2014; Cattane et al., 2015). The EGR and HTR2A genes are expressed in peripheral blood cells (Stefulj et al., 2000; Fukuda et al., 2006; Inoue et al., 2011; Cattane et al., 2015). The peripheral mRNA expression of several genes including the HTR2A gene were shown to have relatively similar expression profiles as in brain tissues (Glatt et al., 2005; Fukuda et al., 2006; Sullivan et al., 2006; Desjardins et al., 2008; Rollins et al., 2010; Yubero-Lahoz et al., 2015; GTExPortal, 2017). In healthy humans, HTR2A gene expression levels in whole blood correlated with 5-HT metabolite levels in the cerebrospinal fluid (Luykx et al., 2016). Peripheral EGR1 expression was increased in patients with schizophrenia compared with healthy controls (Cattane et al., 2015).

Therefore, we expected altered HTR2A expression in response to LSD. Additionally, we hypothesized that LSD acutely increases EGR1 and EGR2 gene expression in humans similarly to rodents.

\section{MATERIALS AND METHODS}

\section{Study Design}

The study used a double-blind, placebo-controlled, cross-over design with two experimental test sessions in balanced order. The washout periods between sessions were at least 7 days. The study was conducted in accordance with the Declaration of Helsinki and International Conference on Harmonization Guidelines in Good Clinical Practice (ICH-GCP) and approved by the Ethics Committee of Northwestern Switzerland. The administration of LSD in healthy subjects was authorized by the Swiss Federal Office for Public Health, Bern, Switzerland. All of the subjects provided written informed consent and were paid for their participation. The study was registered at ClinicalTrials.gov (NCT02308969).

\section{Participants}

Twenty-four healthy subjects (12 men, 12 women; mean age \pm SD: $33 \pm 11$ years; range: $25-60$ years) participated in the study. Blood samples for gene expression measurements were taken from only 15 participants $(7$ men, 8 women; mean age \pm SD: $28.5 \pm 5.8$ years; range: $25-48$ years; mean weight \pm SD: $68 \pm 8 \mathrm{~kg}$; range: $55-85 \mathrm{~kg}$; mean $\mathrm{BMI} \pm \mathrm{SD}$ : $22.0 \pm 2.0 \mathrm{~kg} / \mathrm{m}^{2}$; range: $19-24 \mathrm{~kg} / \mathrm{m}^{2}$ ). The inclusion and exclusion criteria, subjective, autonomic, and adverse effects of LSD, and pharmacokinetic data from this study have been reported in detail elsewhere (Dolder et al., 2016, 2017; Liechti et al., 2017). Briefly, the participants had to be 25- to 65-years old and physically and mentally healthy. Additional exclusion criteria were pregnancy, tobacco smoking ( $>10$ cigarettes/day), 
life-time prevalence of illicit drug use $>10$ times (except tetrahydrocannabinol), and illicit drug use within the past 2 months or during the study (determined by urine drug tests). Of the 15 subjects, only two had used a hallucinogen (LSD and psilocybin) once in their lives.

\section{Study Procedures}

The experimental sessions were conducted in a standard hospital patient room. The participants were resting in hospital beds except when going to the restroom. Only one research participant and one or two investigators were present during the experimental sessions. The participants could interact with the investigator, rest quietly, and/or listen to music via headphones, but no other entertainment was provided. LSD or placebo was administered at 9:00 AM. A standardized lunch and dinner were served at 1:30 and 5.30 PM, respectively. The subjects were never alone during the first $12 \mathrm{~h}$ after drug administration, and the investigator was in a room next to the subject for up to $24 \mathrm{~h}$ while the subject was asleep (mostly from 1:00 to 8:00 AM).

\section{Study Drug}

LSD (D-LSD, Lipomed AG, Arlesheim, Switzerland) was administered in a single oral dose of $100 \mu \mathrm{g}$ as a capsule. The dose was within the range of doses that are taken for recreational purposes (Passie et al., 2008; Nichols, 2016). Corresponding placebo capsules were used.

\section{Measures}

\section{Gene Expression}

Blood samples were collected before and 1.5 and $24 \mathrm{~h}$ after drug administration using the PAXgene ${ }^{\mathrm{TM}}$ Blood RNA system (Becton Dickinson, Heidelberg, Germany). The $1.5 \mathrm{~h}$ time point was selected to coincide with the peak of the plasma concentration of LSD (Dolder et al., 2015b). The $24 \mathrm{~h}$ time point was selected because partial tolerance by that time has been documented (Cholden et al., 1955; Abramson et al., 1956; Belleville et al., 1956). Samples were incubated for $2 \mathrm{~h}$ at room temperature, followed by freezing at $-80^{\circ} \mathrm{C}$ until further processing. Total RNA was prepared using the PAXgene ${ }^{\mathrm{TM}}$ Blood RNA Kit 50 (PreAnalytiX, Qiagen, Hilden, Germany). Total RNA samples were spectrophotometrically scanned (260 and $280 \mathrm{~nm}$; NanoVue, GE Healthcare Life Sciences, Glattbrugg, Switzerland). A260 was used for RNA quantification. The A260/A280 ratio was $>1.9$, excluding relevant protein contamination. RNA quality was also measured using Experion RNA chips (BioRad, Hercules, CA, United States) providing the RNA quality indicator (RQI > 7). Quantitative real-time polymerase chain reaction (PCR) was performed for the HTR2A, EGR1, EGR2, and EGR3 genes and six additional reference genes (ACTB, GAPDH, ALAS1, RPL13A, $P P I A$, and RRN18S) as described previously (Grunblatt et al., 2009). The investigated genes are listed in detail in Table 1. Total RNA (500 ng) from each sample was reverse-transcribed using the iScript cDNA synthesis kit (BioRad, Hercules, CA, United States). Each amplification was performed in a total volume of $10 \mu \mathrm{l}$ that contained $5 \mu \mathrm{l}$ of the QuantiFast SYBR Green PCR kit (Qiagen, Hilden, Germany) and the specific PrimerAssay (Qiagen, Hilden, Germany). The PCR conditions were run on a CFX384 device (BioRad, Hercules, CA, United States) according to manufacturer's manual, with the exception of HTR2A primers, in which annealing occurred at $56^{\circ} \mathrm{C}$ according to a gradient analysis (Qiagen, Hilden, Germany). A meltingpoint analysis was conducted for each assay to confirm the specificity of the PCR products. All of the PCR reactions were run in triplicate. LinRegPCR 2016.0 software (Hart Failure Research Center, Amsterdam, The Netherlands; Ramakers et al., 2003) was used to determine the PCR efficiency. The analysis of gene expression and normalization with the most stable reference genes was conducted using qBasePlus 3.0 software (Biogazelle, Gent, The Netherlands; Vandesompele et al., 2002). Since the consensus is that there are no real reference (housekeeping) genes, there is a need to use more than one reference genes as well as test them before normalization is conducted (Vandesompele et al., 2002). The reference genes GAPDH and PPIA were the least stable and thus excluded, and the normalization analysis was conducted using the four remaining reference genes ( $A C T B$, ALAS1, RPL13A, and RRN18S).

\section{Plasma Concentrations of LSD}

Blood was collected in lithium heparin tubes before and 1, 2, $3,4,6,8,10,12,16$, and $24 \mathrm{~h}$ after LSD administration. The blood samples were immediately centrifuged, and the plasma was rapidly stored at $-20^{\circ} \mathrm{C}$ and later at $-80^{\circ} \mathrm{C}$ until analysis. LSD concentrations in plasma were determined using liquidchromatography-tandem mass-spectrometry as reported in detail elsewhere (Dolder et al., 2015a; Steuer et al., 2016). The lower limit of quantification was $0.05 \mathrm{ng} / \mathrm{ml}$ (Dolder et al., 2015a). The pharmacokinetics of LSD from the present study are presented in detail elsewhere (Dolder et al., 2017).

\section{Statistics}

The statistical analyses were performed using Statistica 12 software (StatSoft, Tulsa, OK, United States). Baseline gene expression values before drug administration were set to 1 , and changes after 1.5 and $24 \mathrm{~h}$ are expressed as fold changes from baseline. Differences between LSD and placebo at the corresponding time points were then analyzed using paired $t$-tests. All comparisons were also made with data standardized to the mean age, body weight, and peak plasma concentrations of LSD. The criterion for significance was $p<0.05$ without correction for multiple comparisons. Additionally, to test for changes in gene expression over time after administration of LSD or placebo, repeated measures analyses of variance (ANOVAs) were conducted with time $(0,1.5$, and $24 \mathrm{~h})$ as within-subject factor followed by Tukey post hoc test. To assess potential moderating effects by sex, sex was added as additional betweensubjects factor to the ANOVAs.

\section{RESULTS}

Three samples after $24 \mathrm{~h}$ had insufficient amounts of RNA to be included in the analysis (Table 2). The expression patterns of the HTR2A, EGR1, EGR2, and EGR3 genes were unchanged 1.5 and $24 \mathrm{~h}$ after the administration of LSD compared with 
TABLE 1 | List of investigated genes.

\begin{tabular}{|c|c|c|c|}
\hline Gene name & Abbreviation & Qiagen (cat. no.) & Gene bank accession no. \\
\hline \multicolumn{4}{|l|}{ Reference genes } \\
\hline$\beta$-Actin & ACTB* & QT00095431 & NM_001101 \\
\hline Glyceraldehydes-3-phosphate dehydrogenase & GAPDH & QT00079247 & NM_002046 \\
\hline Aminolevulinate delta synthase 1 & ALAS1* & QT00073122 & NM_000688 \\
\hline Ribosomal protein L13a & RPL13A* & QT00089915 & NM_012423 \\
\hline Peptidylprolyl isomerase A & PPIA & QT00052311 & NM_021130 \\
\hline 18s ribosomal & RRN18S* & QT00199367 & V01270 \\
\hline \multicolumn{4}{|l|}{ Genes of interest } \\
\hline Serotonin 2 a receptor & HTR2A & QT00054306 & NM_000621 \\
\hline Early growth response 1 & EGR1 & QT00218505 & NM_001964 \\
\hline Early growth response 2 & EGR2 & QT00000924 & NM_000399 \\
\hline Early growth response 3 & EGR3 & QT00246498 & $\begin{array}{l}\text { NM_001199880 } \\
\text { NM_001199881 NM_004430 }\end{array}$ \\
\hline
\end{tabular}

*Most stable reference genes used for normalization.

TABLE 2 | Lysergic acid diethylamide-induced changes in gene expression.

\begin{tabular}{lcccc}
\hline Gene & $\begin{array}{c}\text { Time after } \\
\text { LSD }\end{array}$ & $\boldsymbol{n}$ & $\begin{array}{l}\text { LSD vs. } \\
\text { placebo }\end{array}$ & $\boldsymbol{p}^{\mathbf{a}}$ \\
\hline HTR2A & $1.5 \mathrm{~h}$ & 15 & $0.51(0.13)$ & 0.39 \\
EGR1 & $24 \mathrm{~h}$ & 12 & $0.07(0.02)$ & 0.90 \\
& $1.5 \mathrm{~h}$ & 15 & $-0.1(-0.03)$ & 0.83 \\
EGR2 & $24 \mathrm{~h}$ & 12 & $0.47(0.14)$ & 0.10 \\
& $1.5 \mathrm{~h}$ & 15 & $0.04(0.01)$ & 0.86 \\
EGR3 & $24 \mathrm{~h}$ & 12 & $0.27(0.08)$ & 0.22 \\
& $1.5 \mathrm{~h}$ & 15 & $0.20(0.05)$ & 0.24 \\
\hline
\end{tabular}

HTR2A, serotonin 2a receptor gene; EGR, early growth response gene; $n$, number of samples. ${ }^{a}$ Gene expression values are differences (mean and [SEM]) between $L S D$ and placebo at the respective time point for fold-changes from baseline; $\mathrm{b}$ t-tests.

placebo (Figure 1 and Table 2). Expression did also not change over time after LSD and placebo (HTR2A: $F_{2,24}=0.02, P=1.0$ and $F_{2,26}=1.24, P=0.3$; EGR1: $F_{2,24}=1.14, P=0.3$ and $F_{2,26}=1.9, P=0.2$; EGR2: $F_{2,24}=1.20, P=0.3$ and $F_{2,26}=2.67$, $P=0.09$; EGR3: $F_{2,24}=1.17, P=0.2$ and $F_{2,24}=0.08, P=0.9$, respectively). Sex did not moderate the effects of LSD or placebo on gene expression. Additionally, the findings were similar if the data was standardized to the mean age, body weight or plasma concentration of LSD.

\section{DISCUSSION}

The key finding of the present study was that acute LSD administration did not alter the expression of the HTR2A and EGR1-3 genes in humans using peripheral blood cells as peripheral biomarker possibly reflecting central gene expression. The lack of an acute effect of LSD on HTR2A gene expression in humans is consistent with a study in rats that reported no changes in HTR2A gene expression in different brain areas (Nichols and Sanders-Bush, 2002). However, 5- $\mathrm{HT}_{2 \mathrm{~A}}$ receptor availability may also be altered independently of HTR $2 A$ gene expression (e.g., by receptor internalization or moderation of its activity). Several studies in rats (Buckholtz et al., 1985, 1990; Gresch et al., 2005; Buchborn et al., 2015) reported a decrease in $5-\mathrm{HT}_{2 \mathrm{~A}}$ receptor binding in the prefrontal cortex or consistent trend effects (Buchborn et al., 2015) after repeated LSD administration. Unknown, however, is whether lower binding also occurs after single-dose administration. The present findings of no changes in EGR1 and EGR2 gene expression in human blood samples after acute LSD administration contrast with preclinical findings. Specifically, LSD rapidly increased EGR1 and EGR2 expression in the cortex in rats (Nichols and Sanders-Bush, 2002, 2004; Nichols et al., 2003) and mice (Gonzalez-Maeso et al., 2003, 2007). We expected similar rapid increases in EGR1 and EGR2 expression in humans. Importantly, however, we evaluated gene expression in human blood samples, whereas the animal studies evaluated gene expression in brain tissue. Thus, it is possible that LSD alters gene expression in the brain and not in blood.

Tolerance to repeated LSD administration reportedly begins with the second daily dose of LSD, and complete tolerance develops within 3-4 days of repeated LSD administration in humans according to older studies (Cholden et al., 1955; Abramson et al., 1956; Belleville et al., 1956; Passie et al., 2008; Nichols, 2016) that need to be replicated. In the present study, we found no evidence of acute pharmacological tolerance within $12 \mathrm{~h}$ of acute LSD administration at a dose of $100 \mu \mathrm{g}$ as documented in detail elsewhere (Dolder et al., 2017). Similarly, no acute tolerance was observed after single-dose administration of $200 \mu \mathrm{g}$ LSD in humans within $24 \mathrm{~h}$ (Dolder et al., 2015b, 2017). Thus, after one dose of LSD, subjective effects of LSD were self-reported by the participants as long as LSD was present in plasma, and the subjective effects did not decline more rapidly than the plasma concentrations of LSD (Dolder et al., 2017). This is consistent with the view that LSD directly activates $5-\mathrm{HT}_{2 \mathrm{~A}}$ receptors to produce its mind-altering effects as long as it is present in the effect compartment (i.e., the brain) and assuming largely similar plasma and effect compartment kinetics. The finding of no acute tolerance in the participants in the present study (Dolder et al., 2017) also indicates that no 

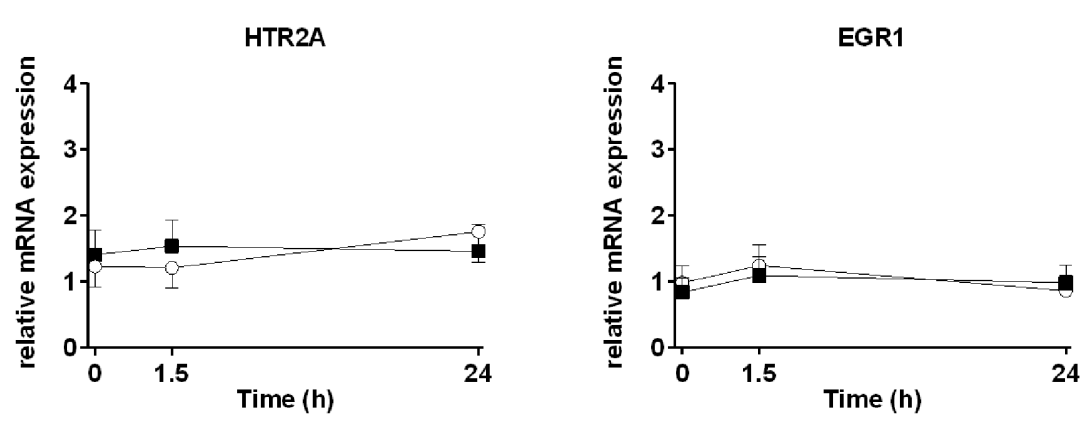

- Placebo
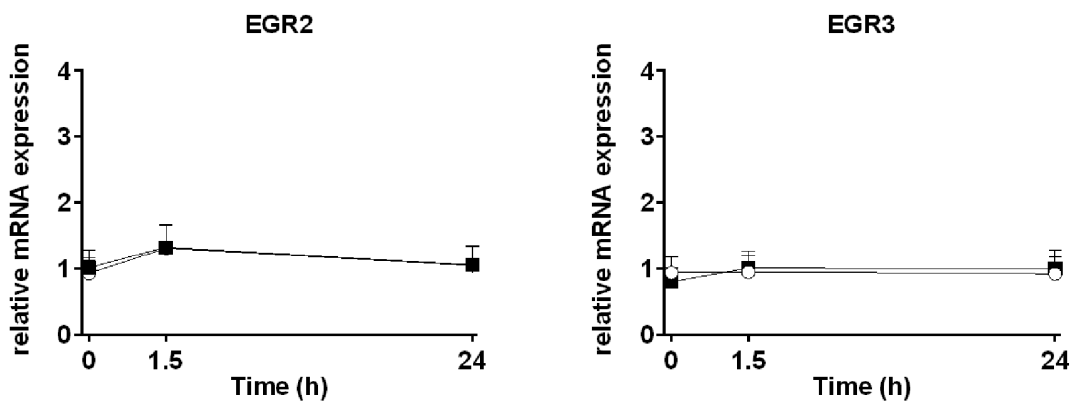

FIGURE 1 | Lysergic acid diethylamide did not alter gene expression. The levels of expression of the 5-HT2A receptor gene (HTR2A) and early growth response genes (EGR1, EGR2, and EGR3) were determined before and 1.5 and $24 \mathrm{~h}$ after administration of $100 \mu \mathrm{g} L S D$ or placebo. The data are expressed as the mean \pm SEM of $m R N A$ expression levels relative to reference genes with stable expression. The respective differences in fold-changes from baseline are show in Table 2.

relevant counterregulatory neuroadaptations occurred or were evident with the first $12-24 \mathrm{~h}$ after LSD administration. A recent study showed that LSD dissociates very slowly from the 5$\mathrm{HT}_{2 \mathrm{~A}}$ receptor, and the authors proposed that the high potency and long effect duration of LSD could be linked to a unique receptor interaction (Wacker et al., 2017). However, the LSD concentration-effect relationship (Dolder et al., 2017) shows that the presence of LSD in the body sufficiently accounted for the duration of its subjective effects. Doubling the LSD dose resulted in prolongation of the effect by approximately $3 \mathrm{~h}$, consistent with its half-life of approximately $3 \mathrm{~h}$ (Dolder et al., 2017). In contrast to the pharmacokinetic-pharmacodynamic relationship of LSD (Dolder et al., 2017), other psychoactive substances, such as 3,4-methylenedioxymethamphetamine (MDMA), exhibit very marked acute pharmacological tolerance, with a rapid decline of subjective and physiological effects of MDMA within $4 \mathrm{~h}$ despite continuously high plasma levels and a relatively long half-life of $8 \mathrm{~h}$ (Hysek et al., 2010; Vizeli and Liechti, 2017).

\section{LIMITATIONS}

The present study has several limitations. First, we assessed the effects of only an acute single dose of LSD on gene expression and tolerance. Further repeated dose administration studies need to be conducted. Second, we used only a moderate single dose of LSD, and the study sample was relatively small. Third, we assessed gene expression only at 1.5 and $24 \mathrm{~h}$ after LSD administration. Therefore, we may have missed effects that may have occurred between these time points. In fact, increases in EGR2 were observed only up to $5 \mathrm{~h}$ in rats (Nichols and Sanders-Bush, 2002; Gonzalez-Maeso et al., 2003; Nichols et al., 2003). Fourth, all changes in gene expression that are caused by LSD that have been reported to date have been observed animal brains, whereas our study focused solely on human blood cells as a peripheral biomarker of the central nervous system (Sullivan et al., 2006; Mohr and Liew, 2007; Desjardins et al., 2008; Belzeaux et al., 2010; Rollins et al., 2010; Rivera-Baltanas et al., 2014; Cattane et al., 2015).

\section{CONCLUSION}

In summary, an acute single dose of LSD in humans did not acutely alter the expression of the HTR2A and EGR1-3 genes in peripheral mononuclear blood cells and thus did not influence potential markers of neuroadaptation.

\section{AUTHOR CONTRIBUTIONS}

Each of the authors participated in this research by contributing to the conception and design of the study (PD and $\mathrm{ML}$ ), study management (PD, FM, and $\mathrm{SB}$ ) performance of laboratory experiments (EG) and statistical analysis and interpretation (PD, $\mathrm{EG}$, and $\mathrm{ML})$. 


\section{FUNDING}

This work was supported by the Swiss National Science Foundation (grant no. 320030_170249 to ML and SB) and the University of Basel (to FM).

\section{REFERENCES}

Abramson, H. A., Jarvik, M. E., Gorin, M. H., and Hirsch, M. W. (1956). Lysergic acid diethylamide (LSD-25): XVII. Tolerance development and its relationship to a theory of psychosis. J. Psychol. 41, 81-105. doi: 10.1080/00223980.1956. 9916206

Belleville, R. E., Fraser, H. F., Isbell, H., Wikler, A., and Logan, C. R. (1956). Studies on lysergic acid diethylamide (LSD-25): I. Effects in former morphine addicts and development of tolerance during chronic intoxication. AMA Arch. Neurol. Psychiatry 76, 468-478. doi: 10.1001/archneurpsyc.1956.02330290012002

Belzeaux, R., Formisano-Treziny, C., Loundou, A., Boyer, L., Gabert, J., Samuelian, J. C., et al. (2010). Clinical variations modulate patterns of gene expression and define blood biomarkers in major depression. J. Psychiatr. Res. 44, 1205-1213. doi: 10.1016/j.jpsychires.2010.04.011

Buchborn, T., Schroder, H., Dieterich, D. C., Grecksch, G., and Hollt, V. (2015). Tolerance to LSD and DOB induced shaking behaviour: differential adaptations of frontocortical 5-HT2A and glutamate receptor binding sites. Behav. Brain Res. 281, 62-68. doi: 10.1016/j.bbr.2014.12.014

Buckholtz, N. S., Freedman, D. X., and Middaugh, L. D. (1985). Daily LSD administration selectively decreases serotonin2 receptor binding in rat brain. Eur. J. Pharmacol. 109, 421-425. doi: 10.1016/0014-2999(85)90407-8

Buckholtz, N. S., Zhou, D. F., Freedman, D. X., and Potter, W. Z. (1990). Lysergic acid diethylamide (LSD) administration selectively downregulates serotonin2 receptors in rat brain. Neuropsychopharmacology 3, 137-148.

Carhart-Harris, R. L., Kaelen, M., Bolstridge, M., Williams, T. M., Williams, L. T., Underwood, R., et al. (2016a). The paradoxical psychological effects of lysergic acid diethylamide (LSD). Psychol. Med. 46, 1379-1390. doi: 10.1017/ S0033291715002901

Carhart-Harris, R. L., Muthukumaraswamy, S., Roseman, L., Kaelen, M., Droog, W., Murphy, K., et al. (2016b). Neural correlates of the LSD experience revealed by multimodal neuroimaging. Proc. Natl. Acad. Sci. U.S.A. 113, 4853-4858. doi: 10.1073/pnas.1518377113

Cattane, N., Minelli, A., Milanesi, E., Maj, C., Bignotti, S., Bortolomasi, M., et al. (2015). Altered gene expression in schizophrenia: findings from transcriptional signatures in fibroblasts and blood. PLoS ONE 10:e0116686. doi: 10.1371/ journal.pone.0116686

Cholden, L. S., Kurland, A., and Savage, C. (1955). Clinical reactions and tolerance to LSD in chronic schizophrenia. J. Nerv. Ment. Dis. 122, 211-221. doi: 10.1097/ 00005053-195509000-00001

Desjardins, S., Belkai, E., Crete, D., Cordonnier, L., Scherrmann, J. M., Noble, F., et al. (2008). Effects of chronic morphine and morphine withdrawal on gene expression in rat peripheral blood mononuclear cells. Neuropharmacology 55, 1347-1354. doi: 10.1016/j.neuropharm.2008.08.027

Dolder, P. C., Liechti, M. E., and Rentsch, K. M. (2015a). Development and validation of a rapid turboflow LC-MS/MS method for the quantification of LSD and 2-oxo-3-hydroxy LSD in serum and urine samples of emergency toxicological cases. Anal. Bioanal. Chem. 407, 1577-1584. doi: 10.1007/s00216014-8388-1

Dolder, P. C., Schmid, Y., Haschke, M., Rentsch, K. M., and Liechti, M. E. (2015b). Pharmacokinetics and concentration-effect relationship of oral LSD in humans. Int. J. Neuropsychopharmacol. 19:pyv072. doi: 10.1093/ijnp/pyv072

Dolder, P. C., Schmid, Y., Mueller, F., Borgwardt, S., and Liechti, M. E. (2016). LSD acutely impairs fear recognition and enhances emotional empathy and sociality. Neuropsychopharmacology 41, 2638-2646. doi: 10.1038/npp.2016.82

Dolder, P. C., Schmid, Y., Steuer, A. E., Kraemer, T., Rentsch, K. M., Hammann, F., et al. (2017). Pharmacokinetics and pharmacodynamics of lysergic acid diethylamide in healthy subjects. Clin. Pharmacokinet. doi: 10.1007/s40262017-0513-9 [Epub ahead of print].

Fukuda, Y., Koga, M., Arai, M., Noguchi, E., Ohtsuki, T., Horiuchi, Y., et al. (2006). Monoallelic and unequal allelic expression of the HTR2A gene in human brain

\section{ACKNOWLEDGMENT}

The authors thank Miryame Hofmann, Susanne KunertDümpelmann, and Sonja Fetz for technical assistance and Michael Arends for text editing.

and peripheral lymphocytes. Biol. Psychiatry 60, 1331-1335. doi: 10.1016/j. biopsych.2006.06.024

Glatt, S. J., Everall, I. P., Kremen, W. S., Corbeil, J., Sasik, R., Khanlou, N., et al. (2005). Comparative gene expression analysis of blood and brain provides concurrent validation of SELENBP1 up-regulation in schizophrenia. Proc. Natl. Acad. Sci. U.S.A. 102, 15533-15538. doi: 10.1073/pnas.0507 666102

Gonzalez-Maeso, J., Ang, R. L., Yuen, T., Chan, P., Weisstaub, N. V., LopezGimenez, J. F., et al. (2008). Identification of a serotonin/glutamate receptor complex implicated in psychosis. Nature 452, 93-97. doi: 10.1038/nature06612

Gonzalez-Maeso, J., Weisstaub, N. V., Zhou, M., Chan, P., Ivic, L., Ang, R., et al. (2007). Hallucinogens recruit specific cortical 5-HT2A receptor-mediated signaling pathways to affect behavior. Neuron 53, 439-452. doi: 10.1016/j. neuron.2007.01.008

Gonzalez-Maeso, J., Yuen, T., Ebersole, B. J., Wurmbach, E., Lira, A., Zhou, M., et al. (2003). Transcriptome fingerprints distinguish hallucinogenic and nonhallucinogenic 5-hydroxytryptamine $2 \mathrm{~A}$ receptor agonist effects in mouse somatosensory cortex. J. Neurosci. 23, 8836-8843.

Gresch, P. J., Smith, R. L., Barrett, R. J., and Sanders-Bush, E. (2005). Behavioral tolerance to lysergic acid diethylamide is associated with reduced serotonin2A receptor signaling in rat cortex. Neuropsychopharmacology 30, 1693-1702. doi: 10.1038/sj.npp.1300711

Grunblatt, E., Bartl, J., Zehetmayer, S., Ringel, T. M., Bauer, P., Riederer, P., et al. (2009). Gene expression as peripheral biomarkers for sporadic Alzheimer's disease. J. Alzheimers Dis. 16, 627-634. doi: 10.3233/JAD-2009-0996

GTExPortal (2017). The Genotype-Tissue Expression (GTEx) Project [Online]. Available at: https://gtexportal.org [accessed December 4, 2017].

Hysek, C. M., Ineichen, M., Nicola, V. G., Simmler, L. D., and Liechti, M. E. (2010). Role of the norepinephrine uptake transporter in the mechanism of action of MDMA (Ecstasy). Eur. Neuropsychopharmacol. 20, S240. doi: 10.1016/s0924977x(10)70296-0

Inoue, M., Okazaki, T., Kitazono, T., Mizushima, M., Omata, M., and Ozaki, S. (2011). Regulation of antigen-specific CTL and Th1 cell activation through 5Hydroxytryptamine 2A receptor. Int. Immunopharmacol. 11, 67-73. doi: 10. 1016/j.intimp.2010.10.007

Kraehenmann, R., Pokorny, D., Vollenweider, L., Preller, K. H., Pokorny, T. Seifritz, E., et al. (2017). Dreamlike effects of LSD on waking imagery in humans depend on serotonin $2 \mathrm{~A}$ receptor activation. Psychopharmacology 234, 2031-2046. doi: 10.1007/s00213-017-4610-0

Lebedev, A. V., Kaelen, M., Lovden, M., Nilsson, J., Feilding, A., Nutt, D. J., et al. (2016). LSD-induced entropic brain activity predicts subsequent personality change. Hum. Brain Mapp. 37, 3203-3213. doi: 10.1002/hbm.23234

Liechti, M. E. (2017). Modern clinical research on LSD. Neuropsychopharmacology doi: 10.1002/jcla.22265 [Epub ahead of print].

Liechti, M. E., Dolder, P. C., and Schmid, Y. (2017). Alterations in conciousness and mystical-type experiences after acute LSD in humans. Psychopharmacology 234, 1499-1510. doi: 10.1007/s00213-016-4453-0

Luykx, J. J., Olde Loohuis, L. M., Neeleman, M., Strengman, E., Bakker, S. C., Lentjes, E., et al. (2016). Peripheral blood gene expression profiles linked to monoamine metabolite levels in cerebrospinal fluid. Transl. Psychiatry 6:e983. doi: 10.1038/tp.2016.245

Maple, A. M., Zhao, X., Elizalde, D. I., McBride, A. K., and Gallitano, A. L. (2015). Htr2a expression responds rapidly to environmental stimuli in an Egr3-dependent manner. ACS Chem. Neurosci. 6, 1137-1142. doi: 10.1021/ acschemneuro.5b00031

Mohr, S., and Liew, C. C. (2007). The peripheral-blood transcriptome: new insights into disease and risk assessment. Trends Mol. Med. 13, 422-432. doi: 10.1016/j. molmed.2007.08.003

Moreno, J. L., Holloway, T., Albizu, L., Sealfon, S. C., and GonzalezMaeso, J. (2011). Metabotropic glutamate mGlu2 receptor is necessary for 
the pharmacological and behavioral effects induced by hallucinogenic 5-HT2A receptor agonists. Neurosci. Lett. 493, 76-79. doi: 10.1016/j.neulet.2011.01.046

Nichols, C. D., Garcia, E. E., and Sanders-Bush, E. (2003). Dynamic changes in prefrontal cortex gene expression following lysergic acid diethylamide administration. Brain Res. Mol. Brain Res. 111, 182-188. doi: 10.1016/S0169328X(03)00029-9

Nichols, C. D., and Sanders-Bush, E. (2002). A single dose of lysergic acid diethylamide influences gene expression patterns within the mammalian brain. Neuropsychopharmacology 26, 634-642. doi: 10.1016/S0893-133X(01)00405-5

Nichols, C. D., and Sanders-Bush, E. (2004). Molecular genetic responses to lysergic acid diethylamide include transcriptional activation of MAP kinase phosphatase-1, C/EBP-beta and ILAD-1, a novel gene with homology to arrestins. J. Neurochem. 90, 576-584. doi: 10.1111/j.1471-4159.2004.02515.x

Nichols, D. E. (2016). Psychedelics. Pharmacol. Rev. 68, 264-355. doi: 10.1124/pr. 115.011478

Passie, T., Halpern, J. H., Stichtenoth, D. O., Emrich, H. M., and Hintzen, A. (2008). The pharmacology of lysergic acid diethylamide: a review. CNS Neurosci. Ther. 14, 295-314. doi: 10.1111/j.1755-5949.2008.00059.x

Preller, K. H., Herdener, M., Pokorny, T., Planzer, A., Kraehenmann, R., Stämpfli, P., et al. (2017). The fabric of meaning and subjective effects in LSDinduced states depend on serotonin 2A receptor activation. Curr. Biol. 27, 451-457. doi: 10.1016/j.cub.2016.12.030

Ramakers, C., Ruijter, J. M., Deprez, R. H., and Moorman, A. F. (2003). Assumption-free analysis of quantitative real-time polymerase chain reaction (PCR) data. Neurosci. Lett. 339, 62-66. doi: 10.1016/S0304-3940(02)01423-4

Rickli, A., Moning, O. D., Hoener, M. C., and Liechti, M. E. (2016). Receptor interaction profiles of novel psychoactive tryptamines compared with classic hallucinogens. Eur. Neuropsychopharmacol. 26, 1327-1337. doi: 10.1016/j. euroneuro.2016.05.001

Rivera-Baltanas, T., Olivares, J. M., Martinez-Villamarin, J. R., Fenton, E. Y., Kalynchuk, L. E., and Caruncho, H. J. (2014). Serotonin 2A receptor clustering in peripheral lymphocytes is altered in major depression and may be a biomarker of therapeutic efficacy. J. Affect. Disord. 163, 47-55. doi: 10.1016/j. jad.2014.03.011

Rollins, B., Martin, M. V., Morgan, L., and Vawter, M. P. (2010). Analysis of whole genome biomarker expression in blood and brain. Am. J. Med. Genet. B Neuropsychiatr. Genet. 153B, 919-936. doi: 10.1002/ajmg.b.31062

Schmid, Y., Enzler, F., Gasser, P., Grouzmann, E., Preller, K. H., Vollenweider, F. X., et al. (2015). Acute effects of lysergic acid diethylamide in healthy subjects. Biol. Psychiatry 78, 544-553. doi: 10.1016/j.biopsych.2014.11.015

Stefulj, J., Jernej, B., Cicin-Sain, L., Rinner, I., and Schauenstein, K. (2000). mRNA expression of serotonin receptors in cells of the immune tissues of the rat. Brain Behav. Immun. 14, 219-224. doi: 10.1006/brbi.1999.0579
Steuer, A. E., Poetzsch, M., Stock, L., Eisenbeiss, L., Schmid, Y., Liechti, M. E., et al. (2016). Development and validation of an ultra-fast and sensitive microflow liquid chromatography-tandem mass spectrometry (MFLC-MS/MS) method for quantification of LSD and its metabolites in plasma and application to a controlled LSD administration study in humans. Drug Test. Anal. 9, 788-797. doi: 10.1002/dta.2042

Strajhar, P., Schmid, Y., Liakoni, E., Dolder, P. C., Rentsch, K. M., Kratschmar, D. V., et al. (2016). Acute effects of lysergic acid diethylamide on circulating steroid levels in healthy subjects. J. Neuroendocrinol. 28:12374. doi: 10.1111/ jne. 12374

Sullivan, P. F., Fan, C., and Perou, C. M. (2006). Evaluating the comparability of gene expression in blood and brain. Am. J. Med. Genet. B Neuropsychiatr. Genet. 141B, 261-268. doi: 10.1002/ajmg.b.30272

Tagliazucchi, E., Roseman, L., Kaelen, M., Orban, C., Muthukumaraswamy, S. D., Murphy, K., et al. (2016). Increased global functional connectivity correlates with LSD-induced ego dissolution. Curr. Biol. 26, 1043-1050. doi: 10.1016/j. cub.2016.02.010

Vandesompele, J., De Preter, K., Pattyn, F., Poppe, B., Van Roy, N., De Paepe, A., et al. (2002). Accurate normalization of real-time quantitative RT-PCR data by geometric averaging of multiple internal control genes. Genome Biol. 3, RESEARCH0034. doi: 10.1186/gb-2002-3-7-research0034

Vizeli, P., and Liechti, M. E. (2017). Safety pharmacology of acute MDMA administration in healthy subjects. J. Psychopharmacol. 31, 576-588. doi: 10. 1177/0269881117691569

Wacker, D., Wang, S., McCorvy, J. D., Betz, R. M., Venkatakrishnan, A. J., Levit, A., et al. (2017). Crystal structure of an LSD-bound human serotonin receptor. Cell 168, 377.e12-389.e12. doi: 10.1016/j.cell.2016.12.033

Yubero-Lahoz, S., Kuypers, K. P., Ramaekers, J. G., Langohr, K., Farre, M., and de la Torre, R. (2015). Changes in serotonin transporter (5-HTT) gene expression in peripheral blood cells after MDMA intake. Psychopharmacology 232, 1921-1929. doi: 10.1007/s00213-014-3827-4

Conflict of Interest Statement: The authors declare that the research was conducted in the absence of any commercial or financial relationships that could be construed as a potential conflict of interest.

Copyright (c) 2017 Dolder, Grünblatt, Müller, Borgwardt and Liechti. This is an open-access article distributed under the terms of the Creative Commons Attribution License (CC BY). The use, distribution or reproduction in other forums is permitted, provided the original author(s) or licensor are credited and that the original publication in this journal is cited, in accordance with accepted academic practice. No use, distribution or reproduction is permitted which does not comply with these terms. 